УДК 378.147: 004.77

UDC 378.147: 004.77

DOI: 10.31475/ped.dys.2018.25.09

\author{
АНАТОЛІЙ ВИХРУЩ, \\ доктор педагогічних наук, проббесор \\ (Україна, Тернопіль, Тернопільський національний \\ економічний університет, вул. Львівська, 11) \\ ANATOLIY VYKHRUSHCH, \\ doctor of pedagogical sciences, professor \\ (Ukraine, Ternopil, Ternopil National Economic University, \\ Lvivska str., 11) \\ ORCID: 0000-0002-1982-0768
}

\title{
Розумове виховання в педагогічній системі Андрея Шептицького (1899-1914 рр.)
}

\section{Intellectual Education in the Pedagogical System of Andrey Sheptytsky (1899-1914)}

У статті охарактеризовано найважливіші аспекти розулового виховання особистості в творчій спадщині видатного мислителя Андрея Шептицького. Розумове виховання розглядається як елелент виховної систели, яка охоплюе всі головні аспекти життедіяльності: віра, жертовна праия для людей, тілесне здоров'я, моральність, подолання нечистоти $i$ n’янства, працьовитість, єдність, ощадливість, застереження від заздрості, нарікань, сприйняття долі $і$ прагнення подолання убогості. Для розуміння суті розумового виховання важливим є звернення Митрополита Андрея до інтелігенції. Акщентовано увагу на питаннях настрою слухачів, запобігання втолі, доречне використання гумору. Для кращого запал'ятовування важливили є п'ятнадиятихвилинні підсулки дня, а також повторення головних думок. Відображено важливість зацікавленості, новизни, доречність поміркованої пристрасності, простоти стилю, мова, образність, порівняння, доступність бесіди, слухання добрих проповідей старших, спільне читання, духовних вправ (реколекції).

Ключові слова: розумове виховання, розвиток, дидактика, педагогіка.

The article describes the most important aspects of intellectual education in the creative heritage of the outstanding thinker Andrey Sheptytsky. Intellectual education is considered as an element of the educational system, which covers all major aspects of life: faith, self-sacrificing work for the benefit of other people, physical health, morality, fighting impurity and drunkenness, diligence, integrity, thrift, avoiding envy and reproach, the right perception of one's fate and desire to overcome poverty. To understand the essence of intellectual education, Metropolitan Andrey's appeal to the intelligentsia is important. Attention is focused on boosting listeners' spirit, prevention of fatigue, appropriate use of humor. Fifteen-minute recollections on the day, as well as the repetition of the main thoughts are important for better memorization. The importance of interest, novelty, significance of moderate passion, simplicity of style, language, imagery, comparison, availability of a conversation, hearing of good sermons of the elders, joint reading, spiritual exercises (recollections) is shown. Specific examples illustrate the importance of uniting nationally minded people, of systemic activities aimed at raising the level of people's culture, while culture is considered as one of the priorities. The problem of knowing the truth, freedom of choice, the search for causal relationships, mutual complementation the theory and actual facts, the school of prayer, the importance of the national university, the concentration of effort, the problem of rational use of time, the importance of silence in the development of personality are singled out. Within the investigated period, attention is focused on the importance of family education; the role of reading is emphasized. The importance of the common pastoral work and mastering the art of sermon, the need for proper respect for the work of teachers is proved.

Key words: intellectual education, development, didactics, pedagogy.

Вступ / Introduction. Проблема розумового виховання залишається до наших днів однією 3 найменш досліджених. Причиною цього явища $е$ недостатня увага до передового досвіду минулих років. Підтвердженням цього е той фракт, що в сучасній европейській дидактиці майже не згадуються видатні вітчизняні мислителі, а рівень обізнаності зі зарубіжними авторами XX ст. не витримуе критики.

Педагогічна система Митрополита Андрея на рівні структурного, фрункціонального, теоретичного моделювання потребуе окремого монографічного дослідження. Спробуемо 
узагальнити доступну інформацію, щодо системи розумового виховання в працях видатного мислителя.

Насамперед доцільно звернути увагу на оцінку особистості Андрея Шептицького. Апостольський Екзарх українців Франції, Швейцарії та країн Бенілюксу Михаїл Гринчишин у передмові до пастирських послань Митрополита Андрея зробив влучне аналітичне узагальнення: «Послання Митрополита мають окрему силу та неначе натхнення згори. Вони просвічують i повчають. У них знаходимо те, що є його особистістю - притаманне йому. Вони віддзеркалюють його власну душу... Не раз думка його підноситься. Немов лет птаха, що з висоти бачить усе краще та ясніше, ніж із землі. У його посланнях знаходимо не лише здорову богословську думку, але також і глибокі фрілософічні рефрлексії. Митрополит чудово бачив психологічні потреби народу. Він на них указував і їх висвітлював. У посланнях бачимо його дари доброго вчителя та катехита... Митрополит не тільки визначний духовний письменник, але силою власної особистости, вродженою геніальністю, проникливим розумом і особистою святістю став він знаряддям Духа Божого. Відчуваємо, що його вустами говорить Дух, який у ньому перебував. У його душі щаслива сполука виняткових людських здібностей із автентичною святістю» (Гринчишин М., 2007).

Постать видатного мислителя і проповідника Християнства викликала закономірний інтерес дослідників. Упродовж останніх років захищені кандидатські дисертації (Л. Крупа, Я. Білас) в яких всебічно висвітлена історична значимість діяльності Митрополита, О. Кекош успішно захистив кандидатську роботу «Просвітницька діяльність та педагогічні погляди Андрея Шептицького», окремі аспекти педагогічної системи Андрея Шептицького розглянуті в докторських дисертаціях М. Ступарика, М. Чепіль, Ю. Щербяка та ін.

Мета та завдання / Aim and tasks. Мета статті - дослідити основні ідеї видатного мислителя Андрея Шептицького, щодо системи розумового виховання.

Завдання дослідження:

1. Проаналізувати особливості розумового виховання в педагогічній системі Андрея Шептицького.

2. 3 позицій системного підходу розглянути зміст пастирських послань митрополита Андрея.

3. Окреслити можливості використання ідей просвітителя в процесі розвитку сучасної фрілософії дидактики.

Методи / Methods. Під час дослідження було використано елементи контент-аналізу, синтез емпіричного матеріалу.

Результати / Results. Аналізуючи пастирські тексти не можна не звернути увагу на одну дивовижну особливість. У 1999 р. Спископ Андрей звертається до вірних Станиславівської єпархії 3 першим словом Пастиря. Окрім релігійних духовних аспектів стаємо свідками добре продуманої, своєрідної педагогічної системи, яка охоплюе всі головні аспекти життедіяльності: віра, жертовна праця для людей, тілесне здоров’я, моральність, подолання нечистоти і п'янства, працьовитість, єдність, ощадливість, застереження від заздрості, нарікань, сприйняття долі і прагнення подолання убогості, «бит економічний», любов до ближніх, родини, вітчизни, застереження від ненависті, співпраця інтелігенщії та священиків для добра народу, пошук правди життя, подолання байдужості, благодійність, просвітництво...

Філософрія освіти, а саме так ми розглядаємо висновки Митрополита, щодо загальних питань розвитку суспільства передбачала визначення головного вектора діяльності. Найважливішим завданням визначено утвердження засад віри і боротьба із злом, яке набуває, на думку А. Шептицького дедалі більшого розмаху. Для вирішення цих завдань на одному з чільних місць самовіддана, ефективна, спільна діяльність священиків. В одному з перших Пастирських послань з красномовною назвою «Наша програма» Спископ Андрей завершує текст молитвою в якій просить про «Духа мудрости та розуму».

Розумове виховання розглядається як елемент системи. Не втрачають значимості наступні тези. По-перше, це своєрідний вектор «правдивої культури», так як «Христова наука працею віків не вичерпала своєї сили культурної. Она носить в собі до тепер через мірну силу поступу i просвіти». По-друге, виокремлюеться економічний чинник в єдності з просвітою, обумовлений тим, що «до багатства суспільність не дійде без правдивої просвіти і без неї легко то, що має, стратить. Для того то справедливо люди цінять собі науку i просвіту. Бо наука для висших верств суспільности є силою в не однім вигляді більшою, чим богатства. Нарід, котрий має учених, здобуває собі в інших признаннє і честь, і люди з ним рахуватися мусять». Зауважимо, що увага до економічних аспектів буде неперервною в працях А. Шептицького: «Треба нам теж брати керму в економічній праці! Треба людям помагати у закладанні християнських крамниць, шпіхлірів, позичкових кас, ріжних господарських і ремісничих спілок та всяких інших під економічним оглядом пожиточних установ» (Пастирське послання Спископа Андрея..., 2007 b). По-трете, серед завдань для учителів як один із головних пріоритетів названий зв'язок теорії з практикою життя: 
«Учіть їх жити. Звертайте їх бажання і охоту до того, що е підставою богацтва і сили народної. Нехай вже молоді діти учаться любити свою землю, нехай учаться діти при ній працювати, нехай будучі покоління візьмуть в свої руки торговлю і промисл, бо слабою завсіди е суспільність, в котрій торгують чужинці. Не ся суспільність щаслива і богата, котра численних має теоретиків, але ся, котра в кожнім напрямі сама собі вистарчае. Виробляйте в молодіжі самостійність, індивідуальність, учіть їх на себе більше числити, ніж на других, не оглядатися на поміч правительства і краю, але власною ініціативою дороблятися самостійного биту» (Пастирське послання Єпископа Андрея..., 2007 а). Цей дивовижний за глибиною документ можна було б прирівняти до рангу філософіï освіти, а ряд пропозицій досягають рівня державної політики. Почетверте, вже в перших зверненнях Спископа Андрея домінуе тема родини, починаючи від сімейних стосунків, підготовки матері до народження дитини, завершуючи організацією виховного процесу в родині: «Ваша хата $е$ першою і найважливішою школою, в якій діти Ваші мають навчитися любити Бога й людей. А якою буде ця школа, такою буде, очевидно, й наука!».

По-п'яте, як окреме завдання виокремлюеться заохочення до читання.

Завершивши півторарічне служіння на рівні Єпископа, ставши Митрополитом, Андрей Шептицький у своерідний спосіб подякував парафіянам, звернувшись до них з Пастирським посланням. Його зміст наповнений не лише релігійною тематикою, але й містить фрілософські, психологічні, педагогічні роздуми. У контексті досліджуваної проблеми виокремимо наступні аспекти. По-перше, акцентуеться увага на двох силах душі, які відрізняють людину від тварини. Це розум і воля. На думку Митрополита з допомогою розуму «пізнаємо, застановляемось, думаємо». Мета розуму пізнавати правду, а воля «е на те, щоб хотіти та бажати добра». По-друге, важливим $е$ висновок, щодо свободи людини, право на вибір. По-трете, вдалі приклади не втрачають значимості до наших днів: «А один пустиножитель, як почав у вечір молитву від слова «Боже безконечної доброти», - так і лишився на цьому слові... Цілу ніч розважав над цими словами і щойно ранком ясне сонце перервало йому це довге та солодке розважання над Божою добротою».

Для розуміння суті розумового виховання важливим е звернення Митрополита Андрея до інтелігенщії (1901р.). У контексті досліджуваної проблеми важливими є два аспекти. По-перше, на початку звернення Митрополит пояснюе особливості пастирських послань до народу: «У листі пастирськім, котрим вітаю вірних моїх епархій, обнімаючи всі верстви нашої суспільности, я змушений уживати способу говоріння, образів і доказів, якнайприступніших для неписьменних людей. Дбаючи о них, на першім місці хочу промовляти способом, їм понятим. У такім, однак, представленню річи не оден важний предмет мусить бути лише поверховно порушений або й зовсім залишений. Доказів можна лиш уживати популярних, котрі не всім вистарчають, а багатьом видаються слабими» (Пастирське послання Митрополита Андрея..., 2007 с). У цьому фрагменті бачимо ряд важливих дидактичних вказівок, які можуть використовувати не лише священики, але й вчителі. Насамперед це усвідомлення необхідності популярного викладу інформації, а також доступність, образність, доказовість, врахування особливостей людей, рівня освіти. По-друге, Митрополит використовуе емоційну аргументацію, яка за глибиною і значимістю досягае методологічного рівня важливого для фрілософії освіти. Підкресливши важливість причинно-наслідкових зв'язків у світі, Митрополит звертаючись до безбожників пише: «Шукаючи найвисшої причини існування мусиш признати, що есть якась сила могуча і творча, котра сей світ i житте на нім в рух впровадила, що початком і мірою всякої моральности, якась сила висша над усе те, що переминає і що зависить в існуванню від інших, якась сила справедлива, котра зрівнає кривди і несправедливості сего світа. Ту силу, могучу, розумну, моральну, справедливу, признаєш, хотяй iї і Богом не називаєш, але, признаючи іï, Бога признаєш. Будь у розумуванню щирим, звернись до простоти, без котрої до людей не трафиш, а у власнім розумі тоги знайдеш певний доказ, що есть Бог на небі - Создатель світа і Судія совісти людської» (Пастирське послання Митрополита Андрея..., 2007 с).

Перший етап діяльності Митрополита Андрея характеризується посиленою увагою до діяльності духовної семінарії у Львові. 1 вересня 1901 р. Митрополит звернувся до настоятелів і учнів із спеціальним листом в якому акцентував увагу на необхідності реформування семінарії. Передбачалося впровадження ліпшої організації, нових правил. Щодо семінаристів підкреслювалася необхідність совісної праці, відповідний спосіб життя, систематичне повторення вивченого, увага до риторики (кращі проповіді виголошувалися в семінарійній каплиці), посильна праця над самим собою, толерантність, вивчення агрономії.

Важливою передумовою успішної діяльності семінарії було створення умов, щоб ректор i префекти могли повністю віддаватися роботі, не маючи потреби в додаткових заробітках і не приймаючи інших зобов'язань.

Митрополит Андрей володіючи високим даром проповідництва щедро ділився своїми роздумами з духовенством. Багато рекомендацій мають педагогічне спрямування і можуть бути 
корисними для вчителів.

Сучасна дидактика лише наближається до ідей проголошених у 1902 р.:

«Єсть, проте, місія проповідею свого рода, одною, хотяй оголошеною через кілька днів з ряду і через кількох проповідників. В тій едності предмету, в тім вспівділанню кількох лежить ціла єї сила. Єдність предмету осягаємо через добре зложений плян місії, в котрім предмети поодиноких наук, з собою зв’язані, взаємно так доповняються, що творять одну цілість, психологічно ведуть до одної мети. Проповідники же, доповняючися взаємно так працею так і прикметами, спільним трудом осягають легко то, чого не міг би осягнути один проповідник». Думаємо, що в педагогіці XXI ст. така організація навчального, виховного процесу поступово стане нормою (Пастирське послання Митрополита Андрея..., 2007 d).

Митрополит характеризуе чотири типи проповідників: катехит, який популярно, ясно викладає матеріал; проповідник, який збуджуе почуття «чувства» слухачів; казуїст аналізуе Закон Божий з допомогою коротких, ясних, практичних прикладів; проповідник сповіді вчить людей сповідатися.

Відзначаємо увагу до настрою слухачів, запобігання втомі, доречне використання гумору.

Для кращого запам'ятовування важливими е п'ятнадцятихвилинні підсумки дня, а також повторення головних думок.

Відзначається також важливість зацікавленості, новизни, доречність поміркованої пристрасності, простота стилю, мова, образність, порівняння, доступність бесіди, слухання добрих проповідей старших, спільне читання, духовні вправи (реколекції).

Важливою є теза про недоцільність надмірної критики слухачів, так як «формальною карикатурою проповідництва есть картанне людей».

Як своєрідний підсумок вищеназваних ідей можна назвати документ, який стосуеться канонічної візитації. Насамперед зауважимо, що Митрополит Андрей починае послання 3 красномовної назви підрозділу: «Моя система». Це важливо для педагогів, так як кожний 3 них дотримуючись загальних засад повинен вибудовувати власне кажучи свою систему. Підкреслюеться важливість доречного зауваження при виявленні недоліків, щоб не образити, а допомогти.

Пізніше цю ідею буде успішно використовувати видатний український педагог В. Сухомлинський в роботі з молодими вчителями.

Не втрачають значимості думки Митрополита Андрея, щодо розумового розвитку дітей: «Катехизуючи, звертаю увагу передовсім на те, чи і оскільки діти розуміють то, що говорять. Бо се річ ясна: чоловік знае лиш то, що розуміе. Задаю, проте, часом питання такі, на котрі не може відповісти той, хто не думае і не розуміе. Суть, очевидно, річі, котрі мусять діти знати напам'ять, але се знанне рішучо не вистарчає; мусить катехіт правду дітям так ясно виложити, щоби дитина розуміла, а так занимаючо, щоби зачала думати. Першою прикметою катехити есть популярність; другою, не меншої ваги, - спосіб, збуджуючий зацікавленне - інтерес» (Пастирське послання Митрополита Андрея..., 2007 е).

Особлива увага звертається на значимість запитань при сповіді, а також на мистецтво проповіді.

Багаторазово Митрополит звертався до проблеми досвіду для ефективного впливу. У концентрованій формі ця думка висловлена в посланні «О квестії соціальній». Двома реченнями вдалося Митрополиту висловити головну суть проблеми: «До чинної праці в тім напрямі потреба немалого досвіду о людях і справах, але досвід мусить на науці опиратися. Небезпеченство з обох сторін есть будувати теорії без уваги на факта і факта студіювати без пам'яти на принципи».

Сучасна дидактика, ще не змогла ощінити роль мовчання в навчально-виховному процесі. У свій час ми спробували виокремити своєрідну фрормулу:

«Людина вчиться багато років, щоб добре говорити і все життя вчиться мовчати». Митрополит Андрей, підкресливши загрозу від «пустої бесіди» оцінив мовчання як знак духовного життя: «Мовчанне душу до неба підносить, всі пристрасті утихомирюе і учить, як для Бога працювати, як Сго справі посвятитися. Де мовчанне заховане, там нема сварні, там неможливі плітки, там о шемранню, о обмові ніколи бесіди нема. Хто мало говорить, рідко коли впаде в якесь ухибленне, той $з$ часом навчиться Бога любити , о Бозі думати, в кожнім найменшім ділі Бога шукати» (Пастирське послання Митрополита Андрея..., 2007 f).

Сучасна дидактика лише наближаеться до розуміння філософіï часу. Митрополит Андрей звертав увагу i на цей аспект. На його думку час присвячений на молитву і духовні вправи найцінніший: «Не тратьте з него ані найменшої хвильки».

Для вчених, молодих дослідників цікавими будуть роздуми Митрополита щодо необхідності концентрації для людей «котрі фахово в однім напрямі ціле житте з муравельною витривалістю $\mathrm{i}$ усильностію працюють для здобуття цілковитол повного знання в своїй спеціальності». 
Митрополита Андрея можна визнати за засновника компаративістики в педагогіщі релігії. Він окреслив напрями досліджень які зберегли актуальність до наших днів. Підкреслена необхідність вивчення спадщини отців церкви, церковної літератури сербів, волгарів, Росії, вітчизняних архівних матеріалів...

Для розвитку економіки і моралі виокремлюеться Митрополитом Андреем значимість культури. Для підвищення рівня культури особлива увага звертається на виховання учнів середніх шкіл для яких важливими є два ідеали християнського життя: ідеали святості та ідеали науки.

Для досягнення мети, для «сповнення нашої місії на думку Митрополита «потреба доконче спеціалістів, котрі би ціле житте посвятили на витривалу працю все в однім напрямі. Нам потреба людей, котрі би, не роздробляючи своїх сил і спосібностей на много, на всі предмети, але скупляючи їх в одній спеціальності, конечно дійшли до того, щоби бути единими найбільшими затоками даного предмета на цілий світ. Non multa sed vultum (краще менше, але краще). Не много предметів, не много книг, а много науки і много праці, вложені в оден предмет, а хотяй би одну лиш книгу. Вистарчить одна справа, перестудіована на ціле житте, але перестудіована так, як досі ніхто з учених ніколи не перестудіював, і так, щоб в тій спеціальності сто літ минуло, заким би ся найшов в світі другий учений, котрий би в той предмет вложив тілько і такої праці» (Пастирське послання Митрополита Андрея..., $2007 \mathrm{~g}$ ).

Ця проблема була такою важливою, що Митрополит багаторазово повертатиметься до неї, підкреслюючи труднощі існуючих умов, відсутність наукових центрів, доступних для українців. Як вихід із ситуації пропонується індивідуальна, системна праця: «Не перечу, що, не маючи своїх університетів і не много наукових посад, в котрих улекшена наукова праця, не маючи наукових бібліотек ані потрібних на наукову працю фондів, не можемо відразу осягнути великих результатів. Можемо однак, мимо того, много зробити. Бо при усильній праці, добрій системі, а передовсім в точно опреділеній спеціальності може писати знамениті праці наукові чоловік, що не жие в великім науковім центрі і не мае під рукою великих бібліотек ані архівів... Нема сумніву, що чоловік, котрий на працю наукову в однім напрямі відкладав би дві, три години денно, через кільканадцять літ з певності дійшов би до незвичайного згнання свого предмету. Для того думаю, що, мимо трудностей нашого положення, не годиться нам зражатися, не годиться рук опускати. Ми повинні противно - якнайсильніше о то старатися, щоби поміж нами чимраз більше находилося людей, готових посвятитися науці, людей, котрі би в науці працювали і приготовлялися до такої праці» (Пастирське послання Митрополита Андрея..., 2007 g).

Для розумового виховання молоді, окрім індивідуальної праці, важливе значення мали i мають університети. Промова Митрополита Андрея в «австрійській Палаті Панів» 3 красномовною назвою «Про потребу українського університету у Львові» вражае глибиною і бездоганною логікою аргументації. Нагадавши, що Україна в XVII ст. мала «квітучі академії», Митрополит зауважив, що саме університети мають колосальний вплив на піднесення культури, «в новітніх часах вони стали найбільшими й найважливішими центрами культурного й національного життя», фонди «віддані на піднесення культурного життя й науки, е, точно говорячи, не видатками, а радше інвестиціями, які приносять велику користь». Зауваживши, що теоретичне визнання права на культуру i абстрактна свобода самостійного розвитку $е$ недостатньою i потребуе державної підтримки, Митрополит підкреслив, що нехтування культурними потребами $є$ «раною, яка мусить принести болючу шкоду організмові нації i, у висліді, також організмові імперії, до складу якої вона належить» (Промова Митрополита Андрея..., 2007 h).

Для розумового виховання молоді вирішальне значення має особистість учителя. Зауваживши, що в добрих учителів «буде добра наука, а злих - зла» Митрополит підкреслював необхідність гідного матеріального статусу учителів: «А як доброго учителя знайдете, то не жалуйте єму грошей, платіть єму добре, бо на добру пенсію заслугуе. Добра наука і добре вихованне дітей - то річ так важна і так цінна, що майже на ню ціни нема» (Пастирське послання Митрополита Андрея..., 2007 i).

Своєрідною вершиною проблематики розумового виховання в спадщині Митрополита Андрея стала ідея про школу молитви. Ї̈̈ суть полягає в тому, щоб «на кожде слово звертати увагу, кожне слово вимовляти душею». Дар молитви розглядається як подарунок Бога, захист від зла, чудо, радість, щастя. У школі молитви важливо розуміти різноплановість, змістовне наповнення кожного слова, так як «одне і те саме слово може мати не раз і кілька ріжних значень, а завсіди може бути висказане з кількома ріжними успособленнями, приміром, слово «Отче», з яким звертаємося до Бога, може бути сказане для вираження чисто природного порядку, без уваги на стан освячуючої благодати. Але може бути бране в значенню відносин прибраних дітей до Отця небесного через Ісуса Христа. Дальше слово «Отче» може бути актом віри, любови, може бути сказане з чувством покаяння, прощення, покори або єще іншими» (Пастирське послання Митрополита Андрея..., 
$2007 \mathrm{j}$ ).

Висновки / Conclusions. Підсумовуючи вищесказане, можна виокремити три основні періоди характерні для діяльності Андрея Шептицького. Перший період, який має ряд субперіодів можна назвати підготовчим. Він завершився в 1888 р. зі вступом до монастиря Другий період, на перший погляд, короткотривалий в часі, але надзвичайно важливий як для Андрея Шептиџького, так і для краю це 1888-1901 рр. Третій період охоплюе час з 1901 р. до 1914 р. Наступні періоди потребують окремого вивчення. Гіпотетично можна передбачити, що період заслання можна назвати четвертим періодом. П'ятий період тривав з 1917 р. до 1939 р., а заключний період, обумовлений початком другої світової війни передбачав зміни в організації діяльності, уточнення авторських концептуальних засад.

Найважливішим досягненням другого і третього періоду стало створення своерідних основ філософії освіти. Це передбачало об’еднання національно свідомих сил, системну діяльність спрямовану на підвищення рівня культури народу, при цьому культура розглядаеться як один із пріоритетів, виокремлюеться проблема пізнання правди, свобода вибору, пошук причиннонаслідкових зв'язків, взаємне доповнення теорії та конкретних фрактів, школа молитви, важливість національного університету, концентрація зусиль, проблема раціонального використання часу, значимість мовчання в розвитку особистості. У досліджуваний період акцентуеться увага на значимості сімейного виховання, підкреслюеться роль читання, доведена важливість спільної душпастирської роботи, мистецтво проповіді, необхідність належного пошанування праці учителів. Кожний з цих елементів знайде подальший розвиток як на теоретичному рівні, так і в практичній діяльності.

\section{Список використаних джерел і літератури / References:}

1. Гринчишин, М. (2007). Введення в книгу. Шептицький Андрей. Пастирські послання 1899-1914 рр. (T. 1, с. VII-XI). Львів: «Артос». / Grynchyshyn, M. (2007). Vvedennia v kn. Sheptytskyi Andrei. Pastyrski poslannia 1899-1914 rr. [Introduction into the book Sheptytsky Andrey. Pastoral Messages of 1899-1914]. (Vol. 1, pp. VIIXI). Lviv: «Artos». [in Ukrainian].

2. Пастирське послання Єпископа Андрея до вірних Станиславівської епархії. (2007 а). Шептицький Андрей. Пастирські послання 1899-1914 рр. (Т. 1, с. 3-18). Львів: «Артос». / Pastyrske poslannia Yepyskopa Andreia do virnykh Stanyslavivskoii yeparkhiii [Pastoral message of Bishop Andrey to the faithful of Stanislaviv diocese]. Sheptytskyi Andrei. Pastyrski poslannia 1899-1914 rr. (Vol. 1, pp. 3-18). Lviv: «Artos». [in Ukrainian].

3. Пастирське послання Єпископа Андрея до духовенства. Наша програма. $(2007$ b). Шептицький Андрей. Пастирські послання 1899-1914 рр. (Т. 1, с. 19-26). Львів: "Артос». / Pastyrske poslannia Yepyskopa Andreia do dukhovenstva. Nasha prohrama. (2007). [Pastoral message of Bishop Andrey to the clergy. Our program]. Sheptytskyi Andrei. Pastyrski poslannia 1899-1914 rr. (Vol. 1, pp. 19-26). Lviv: «Artos». [in Ukrainian].

4. Пастирське послання Митрополита Андрея. До руської інтелігенції. (2007 с). Шептицький Андрей. Пастирські послання 1899-1914 рр. (Т. 1, с. 175-198). Львів: «Артос». / Pastyrske poslannia Yepyskopa Andreia. Do ruskoii intelihentsiii. (2007). [Pastoral message of Bishop Andrey. To the Russian intelligentsia]. Sheptytskyi Andrei. Pastyrski poslannia 1899-1914 rr. (Vol. 1, pp. 175-198). Lviv: «Artos». [in Ukrainian].

5. Пастирське послання Митрополита Андрея. О місіях і духовних вправах. (2007 d). Шептицький Андрей. Пастирські послання 1899-1914 pp. (Т. 1, с. 391-410). Львів: «Артос». / Pastyrske poslannia Yepyskopa Andreia. O misiiakh i dukhovnykh vpravakh. (2007). [Pastoral message of Bishop Andrey. About missions and spiritual exercises]. Sheptytskyi Andrei. Pastyrski poslannia 1899-1914 rr. (Vol. 1, pp. 391-410). Lviv: "Artos». [in Ukrainian].

6. Пастирське послання Митрополита Андрея до духовенства. О канонічній візитації. (2007 е). Шептицький Андрей. Пастирські послання 1899-1914 рр. (Т. 1, с. 411-429). Львів: «Артос». / Pastyrske poslannia Yepyskopa Andreia do dukhovenstva. O kanonichnii vizytatsiii. (2007). [Pastoral message of Bishop Andrey to the clergy. About canonical visitation]. Sheptytskyi Andrei. Pastyrski poslannia 1899-1914 rr. (Vol. 1, pp. 411-429). Lviv: «Artos». [in Ukrainian].

7. Пастирське послання Митрополита Андрея до Сестер служебниць. (2007f). Шептищький Андрей. Пастирські послання 1899-1914 рр. (Т. 1, с. 616-622). Львів: «Артос». / Pastyrske poslannia Yepyskopa Andreia do Sester sluzhebnyts. (2007). [Pastoral message of Bishop Andrey to Sisters of Service]. Sheptytskyi Andrei. Pastyrski poslannia 1899-1914 rr. (Vol. 1, pp. 616-622). Lviv: "Artos». [in Ukrainian].

8. Пастирське послання Митрополита Андрея до духовенства. Зближаються часи... (2007 g). Шептицький Андрей. Пастирські послання 1899-1914 рр. (Т. 1, с. 641-649). Львів: «Артос». / Pastyrske poslannia Yepyskopa Andreia do dukhovenstva. Zblyzhaiutsia chasy.... (2007). [Pastoral message of Bishop Andrey to the clergy. The times are approaching...]. Sheptytskyi Andrei. Pastyrski poslannia 1899-1914 rr. (Vol. 1, pp. 641649). Lviv: «Artos». [in Ukrainian].

9. Промова Митрополита Андрея в австрійській Палаті Панів. Про потребу українського університету у Львові. (2007 h). Шептицький Андрей. Пастирські послання 1899-1914 рр. (Т. 1, с. 718-721). Львів: «Артос». / Promova Mytropolyta Andreia v avstriiskii Palati Paniv. Pro potrebu ukraiinskoho universytetu u Lvovi. (2007). [The speech of Metropolitan Andrey in the Austrian House of Lords. About the need of Ukrainian university in Lviv]. Sheptytskyi Andrei. Pastyrski poslannia 1899-1914 rr. (Vol. 1, pp. 718-721). Lviv: «Artos». [in Ukrainian]. 
10. Пастирське послання Митрополита Андрея Канадийским Русинам. (2007 і). Шептицький Андрей. Пастирські послання 1899-1914 рр. (Т. 1, с. 722-767). Львів: «Артос». / Pastyrske poslannia Yepyskopa Andreia Kanadiiskym Rusynam. (2007). [Pastoral message of Bishop Andrey to the Canadian Rusins]. Sheptytskyi Andrei. Pastyrski poslannia 1899-1914 rr. (Vol. 1, pp. 722-767). Lviv: «Artos». [in Ukrainian].

11. Пастирське послання Митрополита Андрея до духовенства. О молитві і церковнім правилі. (2007 j). Шептицький Андрей. Пастирські послання 1899-1914 рр. (Т. 1, с. 686-705). Львів: "Apтос». / Pastyrske poslannia Yepyskopa Andreia do dukhovenstva. O molytvi i tserkovnim pravyli. (2007). [Pastoral message of Bishop Andrey to the clergy. About prayer and church rules]. Sheptytskyi Andrei. Pastyrski poslannia 18991914 rr. (Vol. 1, pp. 686-705). Lviv: «Artos». [in Ukrainian].

Дата надходження статті: «01» серпня 2018 р.

Стаття прийнята до друку: «20» листопада 2018 р.

Вихрущ Анатолій - професор кафедри психології Тернопільського національного економічного університету, доктор педагогічних наук, професор

Vykhrushch Anatoliy - professor of the department of psychology of Ternopil National Economic University, doctor of pedagogical sciences, professor

Цитуйте ию статтю як:

Вихрущ, А. (2018). Розумове виховання в педагогічній системі Андрея Шептицького Педагогічний дискурс, 25, 72-78.
Cite this article as:

Vykhrushch, A. (2018). Intellectual Education in the Pedagogical System of Andrey Sheptytsky (1899-1914). Pedagogical Discourse, 25, 72-78. 